\title{
CIVIC SPACES AND DESIRE
}

Edited by Charles Drozynski and Diana Beljaars

First published 2020

ISBN: 978-0-8153-9523-2 (hbk)

ISBN: 978-0-8153-9526-3 (pbk)

ISBN: 978-1-351-18413-7 (ebk)

\section{1}

\section{CIVIC SPACE-AND DESIRE-DERANGED}

From Le Corbusier to Georges Perec

Marcus A. Doel

(CC BY-NC-ND 4.0) 


\title{
CIVIC SPACE-AND \\ DESIRE-DERANGED
}

\section{From Le Corbusier to Georges Perec}

\author{
Marcus A. Doel
}

"Our space has strange effects. For one thing, it unleashes desire." (Lefebvre, 1991, p. 97)

"There is desire only if it is desire for the machine." (Guattari, 2006, p. 184) "... what? . . the buzzing? ... yes . . all the time the buzzing . . so-called ..." (Beckett, 1984, p. 220)

The titular phrase "civic spaces and desire" reminds me of the opening lines of Gilles Deleuze and Félix Guattari’s wonderful book, Kafka: Toward a Minor Literature: "How can we enter into Kafka's work?" they ask. "This work is a rhizome, a burrow. . . . We will enter, then, by any point whatsoever; none matters more than another, and no entrance is more privileged even if it seems an impasse, a tight passage, a siphon" (Deleuze and Guattari, 1986, p. 3). How, then, can we enter the burrow or rhizome of civic spaces and desire? Besides the city gates, the main thoroughfares and the subterranean watercourses, the obvious points of entry are "civic spaces" on the one hand and "desire" on the other hand, but I hesitate to choose between them since it is not entirely clear which of them should come first, nor whether they are in fact even separable. My hesitation leads me to reread the opening lines of Le Corbusier's foreword to his seminal text The City of Tomorrow and Its Planning, penned in 1924, with an eye towards the stirring of civic spaces and desire:

A town is a tool. Towns no longer fulfil this function. They are ineffectual; they use up our bodies, they thwart our souls. The lack of order to be found everywhere in them offends us; their degradation wounds our self-esteem and humiliates our sense of dignity. They are not worthy of the age; they are no longer worthy of us.

(Le Corbusier, 1947, p. 13, italics in original) 
This foreword-where towns thwart, offend, wound, degrade and humiliate our efficacy, our dignity, our bodies, our worth and even our souls - is prefaced by an aerial photograph of "a typical London suburb" that Le Corbusier admonishes with the words: "A charming picture which displays every vice of planning!" (Le Corbusier, 1947, p. 12, italics in original). Having foreshown his readers what is undesirable about extant civic space, Le Corbusier goes on to argue that the "City of Tomorrow" must be built anew according to what has been proper to Man since the advent of Homo Erectus - the straight line and the right angle, which are not only "sane and noble" and "the result of self-mastery", he says (Le Corbusier, 1947, p. 30), but that are also truly sublime, especially when arranged to form crosses and iconostases, as in his own 1955 Poem of the Right Angle (Le Corbusier, 2012)-and which must erase the degraded, unworthy and ignoble "City of Today" that has emerged over millennia according to what is fundamentally alien to Man and only really fitting for beasts of burden: the crooked and errant "path of least resistance" (Le Corbusier, 1947, p. 23), whose disorderly and irrational topographic meandering he dubs the pack-donkey's way.

Man walks in a straight line because he has a goal and knows where he is going; he has made up his mind to reach some particular place and he goes straight to it. The pack-donkey meanders along, meditates a little in his scatter-brained and distracted fashion, he zigzags in order to avoid the larger stones, or to ease the climb, or to gain a little shade; he takes the line of least resistance. . . The Pack-Donkey's way is responsible for the plan of every continental [European] city; including Paris, unfortunately.

(Le Corbusier, 1947, pp. 23-24)

Now, I wager that the phrase "civic space" will bring out the more or less latent geometer and geomancer in you, probably under the pretext of enforcing law and order, if only for the reason that "space lays down the law because it implies a certain order-and also a certain disorder" (Lefebvre, 1991, p. 143). Even a barely trodden desire line or desire path lays down the law and commands bodies, as Robinson Crusoe discovered to his fright when he stumbled upon a man's solitary footprint on the sandy shore of his supposedly desolated and deserted Island of Despair:

I stood like one thunderstruck, or as if I had seen an apparition. . . . [A]fter innumerable fluttering thoughts, like a man perfectly confused and out of myself, I came home to my fortification, not feeling, as we say, the ground I went on, but terrified to the last degree, looking behind me at every two or three steps, mistaking every bush and tree, and fancying every stump at a distance to be a man.

(Defoe, 1791, unpaginated) 
Indeed, "nothing and no one can avoid trial by space - an ordeal which is the modern world's answer to the judgement of God or the classical conception of fate" (Lefebvre, 1991, p. 416). However, in these more fluid, flexible and flaccid of times, I suspect that the geometer and geomancer in you will be less fixated on the nobility of the straight line and the right angle, or the dignity of the square and the cube, than Le Corbusier was wont to do:

a modern city lives by the straight line, inevitably; for the construction of buildings, sewers and tunnels, highways, pavements. The circulation of traffic demands the straight line; it is the proper thing for the heart of a city. The curve is ruinous, difficult and dangerous; it is a paralyzing thing. The straight line enters into all human history, into all human aim, into every human act.

(Le Corbusier, 1947, p. 28)

After all, having debased, disgraced and dishonoured the straight line, the square and the cube, the onto-aesthetic taste of today seems to be much more curvaceous, rambling and feral; a derangement well-illustrated by the superimposition of the ludic Parc de la Villette on the post-industrial ruins of Baron Haussmann's original City of Blood (Claflin, 2008; Tschumi, 1994), or even by the sweeping loops of the railway system that Le Corbusier somewhat incongruously proposed for his otherwise rectilinear City of Tomorrow:

It is $9 \mathrm{am}$. From its four vomitories, each 250 yards wide, the station disgorges the travellers from the suburbs. The trains, running in one direction only, follow one another at one-minute intervals. . . The station square is so enormous that everybody can make straight to his work without crowding or difficulty. Underground, the tube taps the suburban lines at various points and discharges its passengers into the basements of the sky-scrapers, which gradually fill up. Every sky-scraper is a tube station.

(Le Corbusier, 1947, pp. 193-194).

Now, given the arrangement of the phrase civic spaces and desire, one may be forgiven for thinking that civic spaces should come first and desire second, as if the first-mentioned were our primary concern and the latter only insofar as it bears on the former: Civic Spaces — and Desire, as it were; where the "- and Desire" arrives belatedly as an afterthought or an after-effect, in keeping, perhaps, with the conviction that "man governs his feelings by his reason" (Le Corbusier, 1947, p. 23). We could then begin to enumerate and explore all of the ways in which desire may come to affect civic space. But what is desire? Understood naively, desire is the desire of a subject (as cause, origin, agent, truth and measure) for an alluring object (real, symbolic or imaginary). Such a desire is always in excess (and therefore both luxuriant and gratuitous) of so-called "needs" (i.e. necessities, use-values) on the one hand and so-called "wants" (i.e. decencies, sign-values) on the other hand, even when the desirable Thing is lacking, like a sinkhole, and precisely because it 
is lacking, like an aporia. A more refined understanding of desire would regard it as an insatiable, interminable and self-referential process of prolongation and procrastination that perpetually differs and defers (i.e. desire desires desire-not satisfaction, not fulfilment, not attainment, not completion, each of which would be fatal to desire and anticlimactic; but perpetuation, augmentation and intensification), or even as the desire for conscious or unconscious recognition - "the desire for a desirer" (Lacan, 2014, p. 24), the "desire for the desire of an another" (Macey, 2000, p. 95) and "the desire of the Other" (Lacan, 2008, p. 38) - that necessarily entails anguish and misrecognition (in short, the desire for desire). However configured, desire would come- belatedly, like a laggard — to affect civic space: from the inside out and the outside in. From the inside out in terms of specifically civic desires that find themselves expressed in civic space, such as those grandiose monuments and memorials that sprout up in public space, like Pyramide du Louvre, Arc de Triomphe de l'Étoile and La Grande Arche de la Défense in Paris. And from the outside in in terms of all of those other desires that would find themselves "out of place", so to speak, in civic space, as evidenced, for example, by the proliferation of all manner of more or less petty prohibitions, such as against ball games, skateboarding, loitering and other incivilities (e.g. spitting, smoking, littering, urinating, honking, heavy petting and suchlike). By folding the inside out and the outside in, civic space and desire would be like the unfathomable, invaginated house in Robert Coover's short story, Playing House:

Once there was a house, the storyteller continues, which was struck by a hurricane and turned inside out, the outside closed within it, its own dimensions infinite and unknowable at what was once the core, more like the edge. Those within moved out, which of course was further in, and there they built a new house looking out in all directions upon the inverted old. Over time, they enlarged the house and as they added rooms, the old house gradually backed away and faded out of sight.

(Coover, 2005, p. 65)

In short, given any civic space whatsoever, one could enumerate all of the desires that could sweep over it, whether civic or not, and consider how they may affect and be affected by one another. Such an encounter between civic space and desire would play out like the "pure machinic filiation" (Guattari, 2006, p. 180) of the alluring orchid and the perverted wasp, each de-territorialising and re-territorialising the becoming of the other through solicitation, penetration and transformation. (For example, what became of Place de Grève following the arrival of the guillotine in 1792, and of the guillotine during its sojourn to Place de la Révolution for the Reign of Terror or even during its confinement to the penal "Houses of Horror" of Nazi Germany?) Naturally, some of these desires would sweep in from the side (i.e. from the realm of everyday life) or swoop down from above (i.e. from a would-be transcendent realm that would lord over everyday life), but many of these desires would surge up from below (i.e. from the "infra-ordinary", as Georges Perec (1999) 
dubbed it). Beneath the paving stones lies the beach, as the famous revolutionary slogan from May '68 poetically expressed the liberation of desire from under the yoke of capitalism and its stooges (teachers, parents, preachers, cops, bureaucrats, politicians, etc.); but beneath the beach lies the magma of the collective unconscious that periodically finds its mob expression: Civic Spaces (- and Desire), so to speak (Badiou, 2012; Bloom, 2012; Ross, 2008). I am reminded of James Cauty's A Riot in a Jam Jar (2011), a series of 1:87 scale dioramas of riotous moments and public order overkill displayed within upturned jam jars.

Now, while one may be forgiven for thinking that civic space should come first and desire second, one may also be forgiven for thinking the converse, since desire was obviously in play long before the emergence of civic space, and indeed long before the emergence of any civility whatsoever. Civic space would be the expression, the repression or the perversion of certain more or less primordial desires, such as topophilia (a love of place) or topophobia (a hatred of place), for example, which have echoed down the ages. Desire would then be under the cosh of civility and under the cloche of civic space, and civic space would be a space of domesticated desires: tamed and docile; enslaved and servile; law-abiding and customary; cold and drab. Whence the continual need to revivify civic space with statues and fountains, banners and bunting, and pomp and ceremony. But all of this will have been in vain.

Order and civility, then, would not so much flow from the outside in, dissipating in the fragmentary space of the utterly chaotic, but would rather surge from the inside out: atomistic, cellular and modular. Here as elsewhere, the Devil is in the detail: doors, windows, handrails, handles, baths, lighting, worktops, etc. Indeed, Flora Samuels (2007, p. 1) argues that nowhere is Le Corbusier's "desperate attempt to create order in what he perceived to be a fragmented and chaotic world . . . better expressed than in the realm of detail". Le Corbusier's buildings were equipped rather than furnished. For example, equipment for dwelling-such as sinks, showers, staircases and storage-enable a house to function as a "machine for living". While many have since recoiled from such a seemingly cold machine, Le Corbusier warmed to its touch. And yet, such a space of quelled desire would no doubt remain haunted by the return of the repressed-wild, unbroken and unbridled desire. For when we speak of civic spaces and desire I wager that the first thing that is called to mind is a more or less violent outburst that shatters the ostensibly serene order of things, from the delirium of spirited haranguers on so many makeshift plinths to the uproar of riotous mobs surging through the streetsalthough I would stress that these spasmodic outbursts are often conjured up and orchestrated by the state and its stooges. After all, those cobbled streets that yearned to be torn up and hurled at the police during May '68 did not pave themselves. Nor did those lamp posts that ached to be transmogrified into impromptu gallows ("à la lanterne!") for the execution of popular (or street) justice during the French Revolution of 1789 illuminate themselves.

Whether one enters the burrow of civic spaces and desire from the side of civic space or from the side of desire, one will sooner or later stumble 
over the seemingly innocuous "and" that comes between them, a conjunction that gathers them up, spins them around and carries them away: and . . and ... and .. . We are not, after all, considering "civic spaces of desire", but "civic spaces and desire". Now, this seemingly innocuous and can be put to work and made to resonate in a great many disparate registers, including: progression (better and better), causation (and then), great duration (on and on), great number (more and more), addition (this and that), differentiation (there are spaces and there are spaces), variety ( $X$ and $Y$ ) and succession (move two and two). Whence the need for "a hinge-logic, a hinge-style" (Lyotard, 1990, p. 123) to articulate and express such a heterogeneous and disjointed multiplicity: for example, by way of the folds of dialectics ("V"), the chiasma of deconstruction ("X") or the schizzes of schizoanalysis ("Z"). Hereinafter, civic spaces and desire slide and glide, like pivoting windows and revolving doors, on these and other hinges - and that leaves geography unhinged and deranged (Doel, 1996, 1999).

This conjunction ["and"] carries enough force to shake and uproot the verb "to be" ["is" and "is not"] . . The middle is by no means an average; on the contrary, it is where things pick up speed. Between things does not designate a localizable relation going from one thing to the other and back again, but a perpendicular direction, a transversal movement that sweeps one and the other away.

(Deleuze and Guattari, 1988, p. 25, italics in original)

Suffice to say that an and is my preferred mode of entry into the burrows of the real, the symbolic and the imaginary. Such an and does not so much conjoin two discrete positions, least of all as an integral, but halves them together and hollows them out, as parasitical differentials that "repeat to differ" in an eternal return (Deleuze, 1994). Begin to tilt or twist or revolve the bar between civic spaces and desire and you may begin to get a sense of what I mean: civic spaces/desire. What returns by way of the slash is neither the same terms nor the same difference between terms, but difference as such, or différance: differing and deferring without origin or end, like the facing off of mirrored skyscrapers in Paris La Défense. Richard McGuire's graphic novel Here (2014), which presents a labyrinth of time cut up in situ, is a perfect rendition of this hinge-logic and hinge-style. The plurality of civic spaces would seem to lean in this direction of dissemination and differentiation. Likewise with the insatiability of desire. Desire stutters and stammers, driven by an insatiable demand: and . . . and . . . and ... "Desiring connection works from term to term, and 'forgets' each as it goes" (Guattari, 2006, p. 30, italics in original). "Where are you going? Where are you coming from? What are you heading for? These are totally useless questions" (Deleuze and Guattari, 1988, p. 25). Since no one truly belongs-belongs as such - to civic space, rather than getting lost in the fabric of the city we are cast adrift in the city. "Voyage in place", quip Deleuze and Guattari (1988, p. 482). 
As for space, which is spaced out and splays out, it also consists of nothing but ands, just as space-time consists of nothing but ands and buts. Accordingly, when I first encountered the phrase "civic spaces and desire" I was immediately struck by its innumerable perforations, its endless openings and its interminable sliding: civic spaces and desire $=$ and $\ldots$ and $\ldots$ and $\ldots$ and $\ldots$ and . . . and . . and. "We will enter, then, by any point whatsoever. . . Only the principle of multiple entrances prevents the introduction of the enemy, the Signifier and those attempts to interpret a work that is actually only open to experimentation" (Deleuze and Guattari, 1986, p. 3). For "if it's true that all desiring connection is revolutionary and subversive . . then analysis opens up onto another world" (Guattari, 2006, p. 151). Such is the force of schizoanalysis, which "follows the machinic indices of deterritorialization" (Deleuze and Guattari, 1984, p. 3). Everything is uprooted and swept away in the revolutionary slipstream of and . . and ... and ...

One key advantage of cleaving to the hinge-logic and hinge-style of the and is that it frustrates the tendency to delimit in advance what will and will not count as civic space, and what will and will not be given over to desire. It also nimbly sidesteps the vexed question of the difference between space and place, their relationship to time (pace, pas) and their qualification as civic. I wager that any attempt to taxonomise civic space will prove inexhaustible and engender a "perfectly astonishing miscellaneity" (Perec, 1999, p. 196), much like the "mind-boggling enumeration" of animals that Perec gleaned from a small selection of French government documents and associated legal texts:

(a) Animals on which bets are laid, (b) animals the hunting of which is banned between 1 April and 15 September, (c) stranded whales, (d) animals whose entry within the national frontiers is subject to quarantine, (e) animals held in joint ownership, (f) stuffed animals, (g) etcetera (this etc. is not at all surprising in itself; it's only where it comes in the list that makes it seem odd), (h) animals liable to transmit leprosy, (i) guide-dogs for the blind, (j) animals in receipt of significant legacies, $(\mathrm{k})$ animals able to be transported in the cabin, (l) stray dogs without collars, (m) donkeys, (n) mares assumed to be with foal.

(Perec, 1999, p. 197, parenthetical remark in original)

I will leave you to list, more or less exhaustively, all of the species of civic space that will ever have existed-intensively and extensively, virtually and actually, in the real, symbolic and imaginary registers, etc.- , starting with an oaken crown (corona civica), perhaps, and ending with a non-human or post-human democratisation of the polis to encompass those "poor in world" (e.g. animals and plants) as well as those "without world" (e.g. stones and rocks), and to ponder where the foregoing civic arrangement of animals should appear in the list, along with this civic arrangement of plants by the Nazis in the Auschwitz (Birkenau) death camp, 
which I am tempted to call a necropolis rather than a metropolis since it was a city of extermination and a regime of horror and terror (Gutman and Berenbaum, 1994; Sofsky, 1997; Wachsmann, 2015).

\section{November 1943}

Objective: to assemble the plants for the purpose of providing a border of greenery for the camp's Nos 1 and 2 crematorium ovens.

Ref: $\quad$ Conversation between SS-Obersturmbannführer Höss, Camp Commandant, and Sturmbannführer Bishoff.

To SS-Sturmbannfuihrer Ceasar, Head of Agricultural Services in the Concentration Camp of Auschwitz (Upper Silesia).

In conformity with an order from SS-Obersturmbannführer Höss, Camp Commandant, Nos 1 and 2 crematorium ovens in the camp will be provided with a green border serving as a natural boundary to the camp.

The following is a list of the plants needing to be drawn from our stocks of trees:

200 trees in leaf from three to five metres high; 100 tree shoots in leaf from a metre and a half to four metres high; lastly, 1,000 bushes for use as lining from one to two and a half metres high, all to come from the stocks in our nurseries.

You are requested to place these supplies of plants at our disposal.

Head of the Central Building Directorate of the Waffen SS and the Police at Auschwitz.

Signed: SS-Obersturmführer (Quoted in Perec, 1999, pp. 90-91)

I mention these seemingly incongruous civic spaces of animals and plants to forestall any overly hasty delimitation of civic space, particularly with respect to orderliness, reasonableness, progressiveness, urbanity and civility, and any overly hasty equation of civic space with so-called open space, public space and the public sphere, such as those buildings, streets, squares, marketplaces, parks, gardens, roundabouts, sports arenas, convention centres, monuments, cemeteries, zoos, newspaper letters pages, online chat rooms, television studios, community halls, swimming pools, polling booths, art galleries, public libraries, civic centres, etc. where "good" people-civic-minded people, the people of civil societytend to gather together to voice their opinions, flex their muscles, vent their fury and generally make a spectacle of themselves: from the dutiful citizenry who profess their devotion to the state when periodically summoned to vote to the riotous mob hell-bent on destroying the existing order of things (Badiou, 2008, 2012).

Recall that this word, civic, from classical Latin, civicus, originally denoted a military honour: a Roman citizen who had saved the life of a fellow Roman 
citizen during warfare would be decorated with a crown, garland or wreath of oak leaves and acorns (corona civica). Only during the French Revolution, at the end of the eighteenth century, did this narrow usage significantly broaden, and it did so in two not entirely complementary directions: on the one hand, civic came to honour the citizen (civis) as such, a citizen no longer cast as a citizen soldier, but recast as an ordinary citizen, a civilian, although the distinction between the civilian sphere and the military sphere is obviously liable to collapse (everything from paramilitary organisations, such as police forces, other so-called emergency services and scouting for boys and girls, to the mobilisation of entire populations to wage total war and the targeting of entire populations in the waging of wars of annihilation and extermination); while, on the other hand, civic also came to honour the town and the city as such (civicus), specifically in the form of the urban, as a locality befitting and characteristic of a community of citizens, and as a locality administered by a community of citizens-so-called civil authority, civilian authority or civilian government.

Just as we tend to forget that the legal form of a commercial company only ceased to be a company of living persons through a series of legal machinations in the second half of the nineteenth century that transformed the company itself into an artificial person (Neocleous, 2003) - a legal personification and subjectivation of capital with plenty of rights, especially property rights (to own, borrow, lend, sue, employ, suffer damages and even will), and hardly any serious responsibilities (alas)- , so we tend to forget that the original form of a town or a city was a fellowship of citizens, which never accounted for all. We, the people, has always been a minority and sectarian affair. And while Roman citizenship remained territorial, Athenian citizenship was "de-spatialised" and "de-territorialised"-leading "to a new kind of identity [for] the citizen, one based on political affiliation alone, on the citizen's belonging to the polis that for the first time gave the citizen a civic presence in the city-state" (Gasché, 2014, p. 25). Uprooted and separated from every kind of identity and bond that had previously tethered them to one another, these newly forged citizens cast adrift in civic space had nothing in common except for their citizenship, a form of citizenship that has subsequently been re-territorialised onto everything from city states and nation states to the world at large and the planet as such.

The [Athenian] reform . . consisted in a territorial reorganization of Attica on the basis of demes (demoi), that is, the smallest local unities of settlements such as townships that were given a political organization and that cut, as it were, through the old order of the phylai (tribes), gene (clans), phratriai (brotherhoods), and thiasoi (cult communities). These demes in turn were used to completely reconstitute and regroup the phylai such that they no longer represented particular, local interests. As a result of this reorganization, the civic body of Attica completely changed, now detached from the local solidarities that until then had cemented the regional factions. . . . [As] a consequence of the reorganization of the tribes and the admission of 
new citizens, such as nonnatives, freed slaves, and foreigners, the reform also brought about a mixing of citizens, one of its most striking aspects.

(Gasché, 2014, pp. 24-25)

With the reassertion and broadening of the notion of the civic in the wake of the French Revolution, which bound together an honouring of the citizen, a veneration of the community of citizens and a glorification of government by the citizenry, all of which was elevated from the confines of the urban to the nation writ large and the universal figure of Man, every space and place, and every nook and cranny, became a civic concern. If the forums, agorae, colonnades, bathhouses, gymnasiums, theatres, amphitheatres, circuses and suchlike were the quintessential civic spaces of Antiquity, where citizens gathered together to do whatever citizens do (Sennett, 1996), then Modernity has levelled such spaces within what I am tempted to call a "civic sprawl". For example, while television injects civic space into the fabric of the home, thereby de-differentiating public and private space, this can nevertheless be resisted. A wonderful instance of such resistance occurred in Poland in 1982, when residents of Swidnik made a public spectacle of their boycotting of the state's news bulletins by either facing their switched-off television sets onto the street or else by taking their unplugged television sets out for an early evening stroll in pushchairs and wheelbarrows, thereby returning the audio-visual drone of the state whence it came (Crawshaw and Jackson, 2010). In this case, civic space belongs as much to the pushchairs and the wheelbarrows, the switched-off and unplugged television sets, and the living rooms and the window frames, as it does to the city's streets, the public's discourses and the broadcasting of the state. Indeed, if I were pressed to single out a few exemplary civic spaces of Modernity, then I would probably foreground barbed-wire enclosures, gas chambers, electric chairs and guillotine scaffolds (Doel, 2017). (For just as the death penalty is arguably what is most properly "human", not only because it is primarily reserved for humans, but also because it places a value on the human that is worth more than life itself (Derrida, 2014), Dr Guillotin's eponymous beheading machine is arguably the perfect citizen: egalitarian, enlightened and humane; and diametrically opposed to the inegalitarian, unenlightened and inhumane forms of spectacular execution in the Ancien Régime. The guillotine was conceived to be a civic-minded citizen fully at home and tirelessly at work in the civic centre of Paris.) But I will resist any such pressure, and simply say that the domain of civic space is illimitable and without taxonomic closure. Hereinafter, any space whatsoever may be qualified as civic_ - or not-, which brings me back to the matter of re-entering the burrow of civic spaces and desire by way of so many differenceproducing ands and buts.

Let me start over again, then, with any heterogeneous assemblage whatsoever, such as windows and wheelbarrows, roundabouts and television sets, barbed wire and bunting, street furniture and wilted lettuce, cobblestones and submarine cables, sewerage and zoos, signage and anthems, lampposts and time zones, refuse and emissions, postage stamps and number plates, or even condiments and the police 
(e.g. Arasse, 1991; Darnton, 2010; Moxham, 2001; Netz, 2009; Schivelbusch, 1992; Sennett, 1996). Civic space would then no longer be grounded in a structure, least of all an infra-structure or a super-structure, but would instead be taken up as a machine. We would no longer ask "what is civic space?" but rather "what becomes of civic space?" And we would seek "not an essence or a position, but a tendency, an orientation-to-change" (Holland, 2013, p. 34), and these can only ever be discerned in context, in situ and au milieu, according to their lines of rigid (molar) and supple (molecular) segmentation, their lines of de-territorialisation and re-territorialisation, and their lines of flight and escape (Deleuze and Guattari, 1986, 1988), and the drive of an "abstract machine, which does not exist but only becomes, which is never fully emerged, but only ever in emergence, [and] is always subject to . . . counter actualisation" (Dowd, 2007, p. 14, italics in original). Indeed, I recall Derrida's (1989, p. 73) characterisation of deconstruction as "a suspicion directed against just that kind of thinking - 'what is . .?'”, a suspicion that Deleuze shared:

The Idea responds only to the call of certain questions. Platonism has determined the Idea's form of question as What is X? This noble question is supposed to concern the essence and is opposed to vulgar questions which point merely to the example or the accident. So, we do not ask who or what is beautiful, but what is the Beautiful. It is not where and when does justice exist, but what is the Just. . . . And yet the privilege accorded the question What is this? reveals itself to be confused and doubtful, even in Platonism and the Platonic tradition... And when we examine the history of philosophy as a whole, we will have a tough time discovering any philosopher whose research was guided by the question What is this? . . The question What is this? . . includes the inessential, and includes it in essence, and thus contradicts itself. Another way of going about it . . . [approaches] the Idea as a multiplicity. . . " [M]ultiplicity" when used as a substantive, designates a domain where the Idea, of itself, is much closer to the accident than to the abstract essence, and can be determined only with the questions who? how? how much? where and when? in which case? - forms that sketch the genuine spatio-temporal coordinates of the Idea.

(Deleuze, 2004, pp. 95-96, italics in original)

Civic spaces and desire should be regarded not as the conjoining of two distinct essences or discrete positions, or the synthesis of two independent structures or separate systems, which may or may not occupy the same level of the sociospatial formation, depending on whether or not desire is regarded as infra-structural (energetic, vitalistic, libidinal, etc.) and civic spaces as super-structural (expressive, symbolic, ideological, etc.) or vice versa, but as a burrow, a rhizome, an assemblage, a multiplicity and a machine. Asking "which one?" rather than "what is?" basically "means this: what are the forces which take hold of a given thing, what 
is the will that possesses it? Which one is expressed, manifested and even hidden in it?” (Deleuze, 1986, p. 71). Asking “what is?” expresses a mode of questioning that draws upon the long-standing complicity between testing, torture and truth (Ronnell, 2005); an inquisitorial mode of questioning that seeks to draw out essence from appearance, an essence that is always already given: pre-formed and pre-fabricated.

When I ask what is this?, I assume there is an essence behind appearances, or at least something ultimate behind the masks. The other kind of question, however, always discovers other masks behind the mask, displacements behind every place, other "cases" stacked up in a case.

(Deleuze, 2004, p. 114, italics in original)

By contrast, asking "which one?" expresses a mode of questioning that opens onto the outside, the forces that traverse it and the problematics that transform it; "never 'What is it?' (the question of being), but 'In which direction is it going?' 'How fast?' 'Along with what else?'” (Holland, 2013, p. 35). So, we will ask of civic space and desire neither what each is nor what each means, but rather what becomes of them. For example, what becomes of a police officer, a demonstrator and a Molotov cocktail that come to engage one another on a dimly lit street corner? Echoing Marx's oft-quoted eleventh thesis on Ludwig Feuerbach-“The philosophers have only interpreted the world, in various ways; the point, however, is to change it" (Marx, 1946, p. 65, italics in original)—, it is a question of opening them up to the outside, to the conjunctures and encounters that make them act, function and work otherwise: and . . and . . and . . but . . but . . but. "There is nothing to explain, nothing to understand, nothing to interpret" (Deleuze, 1977, p. 114). We will enter the fray, then, from the side of the machine, from the side of production, fabrication and manufacture. This is how one becomes engaged.

The question should certainly not be: What is a machine? Or even: Who is a machine? It is not a question of the essence, but of the event, not about is, but about and, about concatenations and connections, compositions and movements that constitute a machine.

(Raunig, 2010, p. 19, italics in original)

Now that we have decided to enter civic space and desire from the side of the machine and engagement, where better so to do than via the opening lines of Deleuze and Guattari's Anti-Oedipus, penned under the surtitle "the desiringmachines", and the subtitle "desiring-production".

It is at work everywhere, functioning smoothly at times, at other times in fits and starts. It breathes, it heats, it eats. It shits and fucks. What a mistake to have ever said the Id. Everywhere it is machines-real ones, not figurative ones: machines driving other machines, machines being driven by 
other machines, with all the necessary couplings and connections. An organmachine is plugged into an energy-source-machine: the one produces a flow that the other interrupts.

(Deleuze and Guattari, 1984, p. 1, italics in original)

For example, suckling and defecating are machinic: a breast is plugged into a mouth and an anal canal is plugged into a rectum, with nourishment and anxiety traversing the former, and faeces and gifts traversing the latter. " Being-for-themachine', that is desire. Not being-for-the-other in general. What an idea!" (Guattari, 2006, p. 184). Likewise for labouring and revolting: a working body is plugged into a body of capital and a nobody is plugged into an uprising, with use-values and exchange-values traversing the former, and justice and fidelity traversing the latter. And when they are all plugged back into civic space they come to concern socalled public health, public decency, public order, public opinion, public policy, public interest, etc. More and more flows, more and more interruptions, intersecting and bisecting, smoothing and striating, splicing and splaying, producing and seducing. Here as elsewhere, "there is no desire other than assembled [agencé] desire" (Smith, 2012, p. 322).

Desiring-machines are binary machines, obeying a binary law or set of rules governing associations: one machine is always coupled with another. The productive synthesis, the production of production, is inherently connective in nature: "and ..." "and then ..." This is because there is always a flow-producing machine, and another machine connected to it that interrupts or draws off part of this flow (the breast - the mouth). And because the first machine is in turn connected to another whose flow it interrupts or partially drains off, the binary series is linear in every direction. Desire constantly couples continuous flows and partial objects that are by nature fragmentary and fragmented. Desire causes the current to flow, itself flows in turn, and breaks the flows.

(Deleuze and Guattari, 1984, p. 5)

Given that "there are Flows; the world presents itself in the form of fluctuation" (Guattari, 2013, p. 75), and so we will enter any civic space whatsoever by way of the energy-source-machines and the organ-machines that connect, disconnect and reconnect with one another to produce the flows and interruptions that will have lent it consistency. Recall, for example, that Le Corbusier's City of Tomorrow has civic-centre railway stations that interrupt the flow of passengers from the suburbs, and that in turn produce a flow of workers through its vomitories that the sky-scrapers interrupt. Here as elsewhere, "the system is demented, yet works very well" (Deleuze, in Guattari, 2009, p. 36). Whether it is civic space or desire, it is an assembly of machines. Such is the world, or, better yet, the "chaosmos", of flow and interruption: and . . and . . and . . but . . but . . but . . "an infernal machine is being assembled" (Guattari, 1984, p. 115), a machinic assemblage that emphasises the consistency of becoming rather than the existence of being: "to 
ex-ist is to stand out" whereas "to con-sist entails being-with rather than standingout: togetherness, the multiple logics of 'and' and 'with' rather than the singular logic of being" (Holland, 2013, p. 11).

We will have entered civic space, then, from the side of the machine and production rather than from the side of the spectacle and reproduction, and specifically from the side of the machinic-cum-schizoanalytic unconscious (Guattari, 2011, 2013), as distinct from both the psychoanalytic unconscious, where everything is "played out in advance, every possible path marked out: the psychoanalytic unconscious was programmed like destiny" (Guattari, 1986, p. 196), and the structural unconscious, where the "sign under erasure" (Nancy and Lacoue-Labarthe, 1992, p. 39) and "the plague of the signifier" (Guattari, 2013, p. 256) run amok. "I call it 'machinic' because it is not necessarily centered around human subjectivity, but involves the most diverse material fluxes and social systems" (Guattari, 1986, p. 194). The unconscious is not a personal, individual or even family drama, but a collective "production of the real, not merely of representation" (Land, 2011, p. 321), and it is not simply a human production, but one that takes in anything and everything: animal, vegetable, mineral, etc. For instance, the entire fabric of the city is bound up with dream-work: not just bedrooms and bathrooms, cinemas and stores, but also bicycles and bar stools, chimneys and subways, razor wire and telegraph poles. "Dissociate subjectivity from the subject, from the individual, and even from the human, and cease considering the power of enunciation exclusive to man and subjectivity" (Lazzarato, 2014, p. 62). Take the gay chatter of commodities in the arcades of Paris, for example, which is oblivious to the presence of consumers, or even the traffic-calming power of a solitary sleeping policeman. A subject is not there from the start, as a foundation or an origin or a cause of desire, but is produced by the machinic unconscious through modes of subjectivation and individuation as an after-effect. "Actually, there is no 'subject of desire', only a production of desire according to a sign machine" (Guattari, 2006, p. 100, italics in original).

We believe the unconscious is not a theatre, but a factory. . . . Saying the unconscious "produces" means that it's a kind of mechanism that produces other mechanisms. In other words, we believe the unconscious has nothing in common with theatrical representation, but with something called a "desiring-machine". . . Desiring consists in interruptions, letting certain flows through, making withdrawals from those flows, cutting the chains that become attached to the flows. . . and contrary to what traditional psychoanalysis tells us, it is perfectly meaningless. Without any sense, there is nothing to interpret. . . The problem is knowing how the unconscious works. It is knowing how "desiring-machines" work, and knowing how to use those machines.

(Deleuze and Guattari, 2004a, p. 232)

We will not, then, enter civic space by way of the customary routes, such as city gates and railway stations, boulevards and promenades, toponyms and statues, 
or URLs and hashtags, nor by way of the customary keywords, such as citizenship, nationalism, democracy or community, all of which presuppose and reinforce the existence of some "one" that is bound together by force and machination, nor by way of the customary activities, such as professing, communing, commuting, demonstrating or protesting, none of which are especially or peculiarly civic, but by way of desiring-machines, desiring-production, and their flows and interruptions: and ... and ... and . . but . . but . . but. This heterogeneous assemblage works, and it works by perpetually breaking down and leaking in all directions. Hereinafter, we will never have pinned or penned down civic space (—and desire), least of all by severing the machinic connections, by guillotining the subject and the object cause of desire, by jamming the concrete and abstract machines, and by proclaiming: "You will be a body_corpse—body_a cadaver, not a machine" (Guattari, 2006, p. 291, italics in original). The city drones on and on.

One will never be done with machinic deterritorialization! It escapes from ordinary laws, hierarchies and metrics. There is no initial state or terminal state with it. . . It is becoming processualizing itself, the heterogeneous in the process of differentiating itself.

(Guattari, 2013, p. 94)

Having entered civic space by way of the gutter, and having lost my way in the labyrinthine garden of forking paths in the civic centre, I will take my leave of this ignoble necropolis in the customary way, by exiting through the gift shop, with a pretty tea towel, a kitsch snow globe and a second-hand jigsaw puzzle expertly crafted by Gaspard Winckler for a certain Mr Bartlebooth of 11 Rue Simon-Crubellier, Plaine Monceau, Paris XVII, which came with an enigmatic handwritten note:

It is the twenty-third of June nineteen seventy-five, and it is eight o'clock in the evening. Seated at his jigsaw puzzle, Bartlebooth has just died. On the tablecloth, somewhere in the crepuscular sky of the four hundred and thirty-ninth puzzle, the black hole of the sole piece not yet filled in has the almost perfect shape of an X. But the ironical thing, which could have been foreseen long ago, is that the piece the dead man holds between his fingers is shaped like a W.

(Perec, 1996, p. 497)

And so, when all is said and done, if an $\mathrm{X}$ were to mark the spot where civic space always already founders on the machinic assembly of desire, then a certain $\mathrm{W}$ may at least come to serve as the vector by way of which other machinations of desiring-production take flight (Guattari, 2015, 2016). This W is perhaps best illustrated not by the likes of Le Corbusier's (1947) City of Tomorrow, and its proclivity for straight lines, right angles and crosses, but by Chris Ware's (2012) Building Stories - for which "some assembly" is obviously required (Doel, 2014; Doel 
and Clarke, 2009) — or, better still, by Perec's own W, or the Memory of Childhood (1988), a story of parallel (and parallax) lives in which "almost every assertion in the memory chapters . . . asks to be questioned, and the answer in most cases is that the memory ... has been altered, reworked, decorated or, more plainly, falsified" (Bellos, 1999, p. 548). The letter W began life as a ligatured doubling of the letters $\mathrm{U}$ and V, a "double U" that graphically recalls the deconstructive play of difference and repetition, reversal and reinscription, and displacement and duplicity - the différance of the eternal return that splays out and hollows out: and . . and . . . and . . . but . . but . . . but. In other words, W marks the spot where X deconstructs and V takes flight (Pynchon, 1963). Hereinafter, civic space and desire scatter. . .

\section{References}

Arasse, D. 1991. The Guillotine and the Terror, trans. C. Miller. London: Penguin.

Badiou, A. 2008. The Meaning of Sarkozy, trans. D. Fernbach. London: Verso.

Badiou, A. 2012. The Rebirth of History, trans. G. Elliott. London: Verso.

Beckett, S. 1984. Not I. In: Samuel Beckett: Collected shorter plays. London: Faber \& Faber, pp. 213-223.

Bellos, D. 1999. Georges Perec: A life in words. London: Harvill.

Bloom, C. 2012. Riot City: Protest and rebellion in the capital. Basingstoke, UK: Palgrave Macmillan.

Cauty, J. 2011. A Riot in a Jam Jar. London: L-13 Light Industrial Workshop.

Claflin, K. 2008. La villette: City of blood (1867-1914). In: P. Y. Lee (ed.), Meat, Modernity, and the Rise of the Slaughterhouse. Lebanon, NH: New Hampshire University Press, pp. 27-45.

Coover, R. 2005. Playing house. In: A Child Again. San Francisco, CA: McSweeney's, pp. 65-87.

Crawshaw, S. and Jackson, J. 2010. Small Acts of Resistance: How courage, tenacity, and ingenuity can change the world. New York: Union Square Press.

Defoe, W. 1791. The Life and Adventures of Robinson Crusoe. The Project Gutenberg, eBook \#521.

Darnton, R. 2010. Poetry and the Police: Communication networks in eighteenth-century Paris. Cambridge, MA: Belknap.

Deleuze, G. 1977. I have nothing to admit, trans. J. Forman. Semiotext(e), 2 (3): 111-116.

Deleuze, G. 1986. Nietzsche and Philosophy, trans. H. Tomlinson. London: Continuum.

Deleuze, G. 1994. Difference and Repetition, trans. P. Patton. London: Athlone Press.

Deleuze, G. 2004. The method of dramatization. In Desert Islands and Other Texts, 19531974, trans. M. Taormina. Los Angeles, CA: Semiotext(e), pp. 94-116.

Deleuze, G. and Guattari, F. 1984. Anti-Oedipus: Capitalism and schizophrenia, trans. R. Hurley, M. Seem and H. R. Lane. London: Athlone Press.

Deleuze, G. and Guattari, F. 1986. Kafka: Toward a minor literature, trans. D. Polan. Minneapolis, MN: University of Minnesota Press.

Deleuze, G. and Guattari, F. 1988. A Thousand Plateaus: Capitalism and schizophrenia, trans. B. Massumi. London: Athlone Press.

Deleuze, G. and Guattari, F. 2004. Capitalism and schizophrenia. In Desert Islands and Other Texts, 1953-1974, trans. M. Taormina. Los Angeles, CA: Semiotext(e), pp. 232-241.

Derrida, J. 1989. Interview by Christopher Norris. In: A. Papadakis, C. Cooke, and A. Benjamin (eds), Deconstruction. Omnibus volume. London: Academy Editions, pp. 71-78. 
Derrida, J. 2014. The Death Penalty. Volume 1, trans. P. Kamuf. Chicago, IL: University of Chicago Press.

Doel, M. A. 2014. And so. Some comic theory courtesy of Chris Ware and Gilles Deleuze, amongst others. Or, an explication of why comics is not a sequential art. In: J. Dittmer (ed.), Comic Book Geographies. Stuttgart: Franz Steiner, pp. 161-180 (text) and 216-223 (images).

Doel, M. A. 1996. A hundred thousand lines of light: A machinic introduction to the nomad thought and scrumpled geography of Gilles Deleuze and Félix Guattari. Environment and Planning D: Society and Space, 14: 421-439.

Doel, M. A. 1999. Poststructuralist Geographies: The diabolical art of spatial science. Edinburgh, UK: Edinburgh University Press.

Doel, M. A. 2017. Geographies of Violence: Killing space, killing time. London, Sage.

Doel, M. A. and Clarke, D. B. 2009. The artistry of cities: Chris Ware's comic strips. In: T. Beyes, S.-T. Krempl and A. Deuflhard (eds), ParCITYpate: Art and urban space. Zurich, Switerland: Niggli, unpaginated.

Dowd, G. 2007. Abstract Machines: Samuel Beckett and philosophy after Deleuze and Guattari. Amsterdam, Netherlands: Rodopi.

Gasché, R. 2014. Geophilosophy: On Gilles Deleuze and Félix Guattari's What is philosophy? Evanston, IL: Northwestern University Press.

Guattari, F. 1984. Molecular Revolution: Psychiatry and politics, trans. R. Sheed. New York: Peregrine.

Guattari, F. 1986. Soft Subversions, trans. D. L. Sweet and C. Wiener. New York: Semiotext(e).

Guattari, F. 2006. The Anti-CEdipus Papers, trans. K. Gotman. New York: Semiotext(e).

Guattari, F. 2009. Chaosophy: Texts and interviews, 1972-1977. Los Angeles, CA: Semiotext(e).

Guattari, F. 2011. The Machinic Unconscious: Essays in schizoanalysis, trans. T. Adkins. Los Angeles, CA: Semiotext(e).

Guattari, F. 2013. Schizoanalytic Cartographies, trans. A. Goffey. London: Bloomsbury.

Guattari, F. 2015. Psychoanalysis and Transversality: Texts and interviews 1955-1971, trans. A. Hodges. South Pasadena, CA: Semiotext(e).

Guattari, F. 2016. Lines of Flight: For another world of possibilities, trans. A. Goffey. London: Bloomsbury.

Gutman, Y. and Berenbaum, M. (eds). 1994. Anatomy of the Auschwitz Death Camp. Bloomington, IN: Indiana University Press.

Holland, E. W. 2013. Deleuze and Guattari's A Thousand Plateaus: A reader's guide. London: Bloomsbury.

Lacan, J. 2008. My Teaching, trans. D Macey. London: Verso.

Lacan, J. 2014. The Seminar of Jacques Lacan. Book X: Anxiety. ed. J.-A. Miller, trans. A. R. Price. Cambridge: Polity.

Land, N. 2011. Fanged Noumena: Collected writings, 1987-2007. Falmouth, UK: Urbanomic.

Lazzarato, M. 2014. Signs and Machines: Capitalism and the production of subjectivity, trans. J. D. Jordan. Los Angeles, CA: Semiotext(e).

Le Corbusier. 1947 [1924]. The City of To-Morrow and Its Planning, trans. F. Etchells. London: Architectural Press.

Le Corbusier. 2012 [1955]. Le poème de l'angle droit. Berlin, Germany: Hatje Cantz.

Lefebvre, H. 1991. The Production of Space, trans. D. Nicholson-Smith. Oxford: Blackwell.

Lyotard, J.-F. 1990. Duchamp's Trans/formers. Venice, CA: Lapis.

Macey, D. 2000. Dictionary of Critical Theory. London: Penguin. 
Marx, K. 1946 [1845]. Theses on Feuerbach. In F. Engels, Ludwig Feuerbach and the End of Classical German Philosophy. Moscow, Russia: Progress, pp. 61-65.

McGuire, R. 2014. Here. London: Hamish Hamilton.

Moxham, R. 2001. The Great Hedge of India. London: Constable.

Nancy, J.-L. and Lacoue-Labarthe, P. 1992. The Title of the Letter: A reading of Lacan, trans. F. Raffoul and D. Pettigrew. Albany, NY: SUNY.

Neocleous, M. 2003. Staging power: Marx, Hobbes and the personification of capital. Law and Critique, 14 (2): 147-165.

Netz, R. 2009. Barbed Wire: An ecology of modernity. Middletown, CT: Wesleyan University Press.

Perec, G. 1988. W, or the Memory of Childhood, trans. D. Bellos. Boston, MA: David Godine.

Perec, G. 1996. Life: A user's manual, trans. D. Bellos. London: Harvill.

Perec, G. 1999. Species of Spaces and Other Pieces, trans. J. Sturrock. Harmondsworth, UK: Penguin.

Pynchon, T. 1963. V. London: Jonathan Cape.

Raunig, G. 2010. A Thousand Machines: A concise philosophy of the machine as social movement, trans. A. Derieg. Los Angeles, CA: Semiotext(e).

Ronnell, A. 2005. The Test Drive. Chicago, IL: University of Illinois Press.

Ross, K. 2008. The Emergence of Social Space: Rimbaud and the Paris commune. London: Verso.

Samuel, F. 2007. Le Corbusier in Detail. Oxford: Architectural Press.

Schivelbusch, W. 1992. Tastes of Paradise: A social history of spices, stimulants, and intoxicants, trans. D. Jacobson. New York: Vintage.

Sennett, R. 1996. Flesh and Stone: The body and the city in Western civilization. New York: W.W. Norton.

Smith, D. W. 2012. Essays on Deleuze. Edinburgh, UK: Edinburgh University Press.

Sofsky, W. 1997. The Order of Terror: The concentration camp, trans. W. Templer. Princeton, NJ: Princeton University Press.

Tschumi, B. 1994. Architecture and Disjunction. London: MIT Press.

Wachsmann, N. 2015. KL: A history of the Nazi concentration camps. London: Little, Brown \& Co.

Ware, C. 2012. Building Stories. London: Jonathan Cape. 